https://nv.nltu.edu.ua

https://doi.org/10.36930/40310516

Article received 29.10.2021 p.

Article accepted 25.11.2021 p.

$@ \bowtie$ Correspondence author

O. I. Strogan

UDC 004.775:515.2

І. Г. Свідрак, Л. І. Шевчук, О. І. Строган, Л. Р. Струтинська, І. В. Строган

Національний університет "Львівська політехніка", м. Львів, Україна

\title{
КІНЕМАТИЧНЕ ПРОЕЦІЮВАННЯ ЯК ЗАСІБ УПРАВЛІННЯ ТЕХНІКОЮ В АВТОМАТИЗОВАНИХ ЗЕМЛЕОБРОБНИХ КОМПЛЕКСАХ
}

Досліджено методику застосування кінематичного проеціювання для відображення траєкторії руху та пошуку координат рухомих об'єктів. З'ясовано, що специфікою кінематичного проеціювання є те, що всі ії ключові складові, а саме - об'єкт, центр проеціювання, картинна площина та проектувальні промені, перебувають у неперервному русі із певними швидкостями та пришвидшеннями. Така специфічна особливість кінематичного проеціювання не тільки істотно розширює технологічні можливості нарисної геометрії як науки про графічне відображення просторових об'єктів, а й істотно поглиблює галузі практичного її застосування. Встановлено, що підтвердженням цьому є розглянуті у цій роботі приклади практичного застосування специфіки кінематичного проеціювання для вдосконалення дистанційного керування землеобробною технікою в автоматизованих комплексах управління. З'ясовано, що це дає змогу усувати негативний вплив "людських чинників" операторів, що відстежують траєкторії переміщень техніки оброблюваною земельною ділянкою. Досліджено, що основні складові технічного забезпечення практичного застосування кінематичного проеціювання для відстежування переміщень землеобробної техніки й різних транспортних засобів полягає в оснащені відеокамерами та приладами електромагнітного випромінювання стаціонарні радіовежі або безпілотні літальні апарати (БПЛА), наприклад, дрони, що виконуватимуть функції центрів кінематичного проеціювання. Рекомендовано, що сприймання генерованих центром проеціювання проектувальних променів тут може бути покладено на оснащений радіолокаційною системою (РЛС) та сучасним комп'ютерним спорядженням із відповідним програмним забезпеченням стаціонарний командний пункт (центр). Це устаткування, у цьому випадку, виконуватиме функцію "картинної площини", на якій відображатиметься траєкторія руху землеобробної техніки. 3'ясовано, що виконавчі механізми та органи управління рухом землеобробної техніки у цьому випадку доречно оснастити пристроями, що приймають керівні радіохвилі. Показано, що окрім відстежування траєкторії рухів об'єктів на земній поверхні, кінематичне проеціювання може застосовуватися й у військовій справі для виявлення ворожих безпілотних об'єктів у повітряному просторі. У цьому разі використовують різновид кінематичного проеціювання із двома його центрами генерування проектувальних променів.

Ключові слова: нарисна геометрія; центр проеціювання; рухомий об'єкт, картинна площина; землеобробна техніка; дистанційне керування; літальні об'єкти.

\section{Вступ / Introduction}

Розвиток упродовж останніх десятиліть космічної техніки, засобів зв'язку та комунікацій, комп'ютерних мереж тощо неодмінно мали зумовити формування i постановку нових задач і проблематик перед інженерною наукою. Зокрема, і як щодо спроможностей забезпечення не тільки підвищених швидкостей просторових переміщень різноманітних об'єктів, а й стосовно теоретичного опису та відображення координатної прив'язки рухомих об'єктів та засобів контролю їх стану і переміщень. Проблематика потреби невпинного контролю за рухомими об'єктами сприяла не тільки стрімкому роз- витку сучасних технічних засобів радіозв'язку та передачі інформації, а й певною мірою дотичних до опису рухомих об'єктів наук, зокрема, аерофотогеодезії, оптичної фізики, певних напрямів математики, покликаних теоретично описати й обгрунтувати закономірності ix pyxy.

Торкнулась ця проблематика й такої складової математичної науки, як нарисна геометрія. Зокрема, перед нарисною геометрією, як наукою геометричного відображення взаєморозташування елементів простору, постало завдання створення теорії кінематичного відображення. Під "кінематичним відображенням" потрібно розуміти проеціювання, за якого всі його елементи, а

Інформація про авторів:

Свідрак Інга Гаріївна, канд. техн. наук, доцент, кафедра нарисної геометрії та графіки. Email: svidrak99@gmail.com; https://orcid.org/0000-0003-1811-2011

Шевчук Лілія Іванівна, д-р техн. наук, професор, кафедра технології органічних продуктів. Email: shev.lili2206@gmail.com; https://orcid.org/0000-0001-6274-0256

Строган Орися Іванівна, канд. техн. наук, ст. викладач, кафедра нарисної геометрії та графіки. Email: Orestastrogan@gmail.com; https://orcid.org/0000-0002-1790-6736

Струтинська Леся Романівна, канд. екон. наук, доцент, кафедра менеджменту персоналу та адміністрування. Email: lesyastrutyn@gmail.com; https://orcid.org/0000-0002-0401-5475

Строган Іван Васильович, студент, інститут будівництва та інженерії середовища. Email: ivan.Strohan.HB.2020@lpnu.ua

Цитування за ДСту: Свідрак І. Г., Шевчук Л. І., Строган О. І., Струтинська Л. Р., Строган І. В. Кінематичне проеціювання як засіб управління технікою в автоматизованих землеобробних комплексах. Науковий вісник НлТУ України. 2021, т. 31, № 5. С. 102-107.

Citation APA: Svidrak, I. H., Shevchuk, L. I., Strogan, O. I., Strutynska, L. R., \& Strogan, I. V. (2021). Kinematic projection as a means of technology control in automated tillage complexes. Scientific Bulletin of UNFU, 31(5), 102-107. https://doi.org/10.36930/40310516

102 Науковий вісник НЛТУ України, 2021, т. 31, № 5

Scientific Bulletin of UNFU, 2021, vol. 31, no 5 
саме центр проеціювання, фокальні фігури проеціюючих комплексів і конгруенцій, об'єкт проеціювання (прообраз) та носій проекцій ("картинна площина") можуть здійснювати взаємонезалежні просторові переміщення у просторі й часі.

Об'єкт дослідження - кінематичне проеціювання як засіб відображення координат і траєкторій переміщень просторових об'єктів.

Предмет дослідження - застосування методик розв'язання прямої та оберненої задач кінематичного проеціювання для відображень траєкторій рухів наземної техніки та пошуку координат просторового розташування безпілотних літальних об'єктів.

Мета роботи - розробити принципові схеми й алгоритми розв'язку прямої та оберненої задач кінематичного проеціювання щодо їх застосування для підвищення якості оброблення землі в автоматизованих землеобробних комплексах та пошуку координат просторових переміщень літальних об'єктів.

Для досягнення зазначеної мети визначено такі основні завдання дослідження:

- створити алгоритм побудови проекцій траєкторій просторових переміщень об'єктів кінематичного проеціювання;

- розробити принципову схему вдосконаленого методикою кінематичного проеціювання автоматизованого землеобробного комплексу;

- розробити методику використання алгоритму розв'язання "оберненої задачі" кінематичного проеціювання для пошуку в повітрі та товщі води рухомих об'єктів.

Наукова новизна отриманих результатів дослідження - вперше вдосконалено метод кінематичного проеціювання, що дає змогу розширити галузь застосування методик і засобів нарисної геометрії на рухомі у просторі та часі об'єкти.

Практична значущість результатів дослідження створено схеми й алгоритми розв'язання задач кінематичного проеціювання для побудов траєкторій рухів наземного автоматизованого землеобробного устаткування та пошуку координат просторового розташування літальних апаратів, наприклад, ворожих розвідувальних дронів (у назві статті йдеться про автоматизовані землеобробні комплекси, причому тут розвідувальні дрони).

Аналіз останніх досліджень та публікацій. Одним iз перших фундаментальних досліджень у галузі кінематичних проблем графічних відображень можна вважати опубліковану в 1936 р. роботу М. А. Риніна "Кіноперспектива" [12]. У цій роботі розглянуто деформації кінозображення рухомих предметів. Тут же досліджено й зворотну задачу, визначено складові руху об'єкта за його кінематографічним відображенням. Описано також певні часткові випадки руху оригіналу, зокрема, прямолінійні, що перпендикулярні до "картинної площини", а також обертові.

Дослідженнями Л. М. Ліхачова, що відображені в роботах $[6,7]$, було систематизовано попередній досвід кінематичного проеціювання. У його опублікованій в 1975 р. монографії "Кіноперспектива" досліджено проблематику реконструювання просторових форм і траєкторій руху об'єкта, методи визначення швидкостей i прискорень тощо. В основу запропонованої Л. М. Ліхачовим кіноперспективи покладено запроваджене ним поняття "кванта руху", під яким розуміють певну абстрактну величину $\Delta S=\Delta x+\Delta y+\Delta z$ миттєвого просторового переміщення точки за інтервал часу $t$. Квант руху фігури визначається системою квантів руху окремих іiі точок [8]. Після цього розглядаються перспективні зображення квантів руху відрізків і площин, які автор назвав квантограмами, та проводиться їх реконструкція і аналіз.

Роботи О. К. Кульмінського $[4,5]$ присвячено проблематиці кіноперспективи та кіноаксонометрії як методу об'ємно-графічного моделювання. Тут же розглядають і перспективу застосування кіноаксонометрії до проектування автомобільних шляхів.

У дослідженнях В. Є. Михайленко і М. В. Ковтун [9] розглядають проектування так званим "пласким" жмутком, що переміщається у вертикальному напрямку. У цьому випадку кінематичні "щільові" фотографування дають змогу усунути традиційне проеціювання із декількох центрів і притаманне йому "змазування" зображення на картинній площині. Картинна основа тут, зазвичай, перпендикулярна до траєкторії руху центра. У роботі розглянуто проеціювання лінійних і нелінійних (2-го порядку) об'єктів та реконструкція прообразів за власними та відкинутими тінями.

У роботі Д. І. Ткач [13] досліджено центрове рухоме проеціювання, у якому траєкторія центру проектування прямолінійна й перпендикулярна до площини проекцій, а прообрази нерухомі. Тут встановлено існування простору-проекції, який перебуває у перспективному зв'язку із простором-оригіналом і бієктивна відповідність між цими просторами.

В опублікованій у 1991 р. роботі [11] автора С. Ф. Пилипака подано алгоритмічний опис послідовності визначення точок твердого тіла, що переміщається по просторовій криволінійній траєкторії з допомогою проеціювання із нерухомого центра на рухому площину.

Вагомий внесок у становлення та розвиток кінематичного проеціювання зробили науковці НУ "Львівська політехніка" В. М. Глоговський та І. Г. Пулькевич. У їхніх роботах $[3,10]$ вперше було запропоновано використання розроблених ними лінійних операторів для грамографічних, ротографічних та спінографічних відображень рухомих об'єктів простору.

Поряд із створенням алгоритмів розв'язань прямої задачі кінематичного проеціювання для пошуку проекцій траєкторій просторових переміщень об'єктів автори $[1,2]$ розробили і грунтовно дослідили також і алгоритми розв'язання оберненої задачі. Обернена задача передбачає пошук за відомими траєкторією руху координат просторового розташування об'єкта.

Отже, потрібно відзначити, що науковці-геометри усвідомили проблематику та потребу в переході від вже долові досконало вивченого статичного проеціювання до кінематичного.

Теоретичною основою досліджень були положення сучасної нарисної геометрії як науки про відображення елементів простору, доповненої специфікою відтворення динаміки як рухомих об'єктів, так і просторових переміщень складових ортогонального проеціювання. Серед загальних методологічних підходів, які характеризують класичну та сучасну теорії розвитку засобів проеціювання, використано положення теорій системноструктурного аналізу для розроблення алгоритмів послідовностей побудов проекцій траєкторій просторових переміщень об'єктів простору. Під час розроблення структурних схем гомографічного відображення траєкторій рухів та для визначення координат об'єктів 
проеціювання, поряд із графічним та розрахунковоконструктивним методологіями дослідження, застосовували для узагальнення результатів методики екстраполяції на основі абстрактно-логічних підходів.

\section{Результати дослідження та їх обговорення / Research results and their discussion}

Дослідження кінематичних проекційних відображень доцільно почати з розгляду лінійних операторів. Зокрема, для систематизації сполучення основних видів руху, що розглядають у цій роботі, потрібно дослідити грамографічне відображення - відображення, за якого всі елементи проекційного апарату здійснюють прямолінійні рухи (рис. 1).

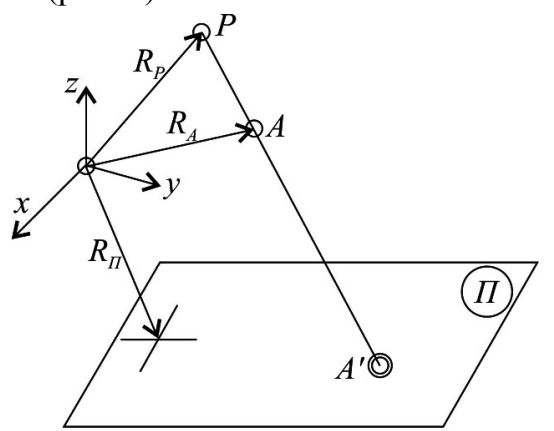

Рис. 1. Принципова схема грамографічного відображення проекцій точки при центровому кінематичному проеціюванні / Schematic diagram of the gramographic display of point projections in the central kinematic projection

Умовно кінематичні відображення лінійними операторами позначають

$$
F: A_{j} \frac{P_{i}}{(\ldots)} \rightarrow A_{j}(j=1,2, \ldots) .
$$

При цьому взято до уваги, що проеціювання здійснюється при одночасних та взаємонезалежних рухах всіх елементів відображення (прообразу $A$, центра проеціювання $P$ і носія образів $\pi)$ :

$$
r_{a}: A_{j}=A_{j}(t) ; \quad r_{p}: P_{j}=P_{j}(t) ; \quad r_{\pi}: \pi_{j}=\pi_{j}(t),
$$

де: $(.$.$) - у дужках позначають види рухів: \gamma$ - прямолінійний, $\rho$ - обертовий, $\sigma-$ гвинтовий.

Графічне відображення лінійними операторами здійснюється за допомогою вироджених комплексів нульової кривини, зокрема, центровим проеціюванням за таким алгоритмом:

$$
\begin{gathered}
F: A_{j} \frac{P_{i}}{(\ldots)} \rightarrow A^{\prime}{ }_{j}(j=1,2, \ldots) . \\
r_{a}: A_{j}=A_{j}(t) ; r_{p}: P_{j}=P_{j}(t) ; r_{\pi}: \pi_{j}=\pi_{j}(t) . \\
P_{j} \cup A_{j}=S_{j}, S_{j} \cap \pi_{j}=A_{j}^{\prime},\left\{A_{j}^{\prime}\right\} \supset A_{1}^{\prime}, A_{2}^{\prime}, \ldots
\end{gathered}
$$

Будемо вважати, що між кінематичними режимами руху (швидкість, прискорення) точки та центра проеціювання і порядком променевої проеціюючої поверхні виведені та досліджені рівняння первинних і вторинних проекцій траєкторій прообразу $A$ при: рівномірному русі $A$ та рівнозмінному русі центра проеціювання $P$; рівномірному русі $A$ і $P$ в спеціалізованому положенні, коли $A_{0}\left(x_{01}, 0, Z_{01}\right), P_{0}\left(x_{02}, y_{02}, 0\right)$. На основі виведених рівнянь необхідно визначити види траєкторій прообразу рухомого об'єкта.

Нехай $f_{1}\left(y=y_{1} ; z=k_{z} ; x=b_{z}\right)$ i $f_{2}\left(x=x_{2} ; z=z_{2}\right)$ - прямолінійні траєкторії руху відповідно прообразу (точки) $A$ й центра проеціювання $P$, які починають одночасно рухатись: точка $A$ - рівномірно зі швидкістю $v_{0}$ і прискоренням $a$ (рис. 2).

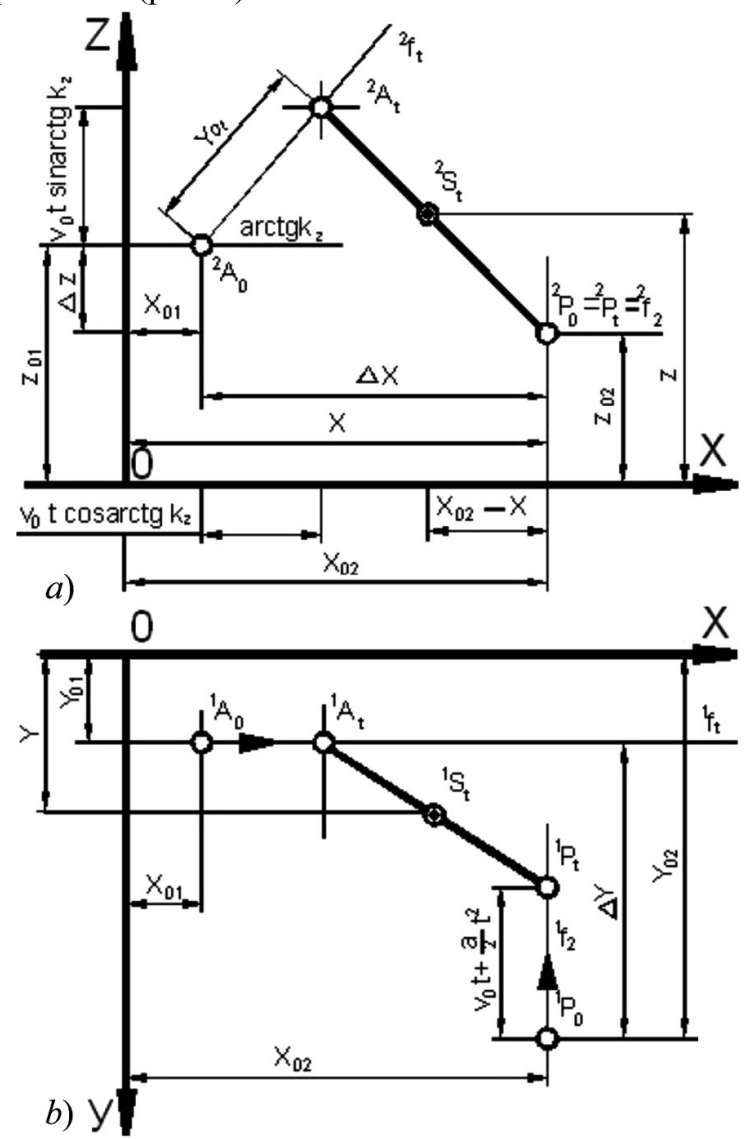

Рис. 2. Грамографічні відображення проекцій рухомих об'єкта (точка A) та центра проеціювання (точка $P_{0}$ ) на епюрі Монжа / Gramographic representations of projections of a moving object (point A) and the center of projection (point $P_{0}$ ) on Monge diagram

Задані умови руху виділяють із лінійчатої конгруенції $s^{2}\left(f_{1} ; f_{2}\right)$ з фокальними фігурами $f_{1}$ і $f_{2}$ променеву поверхню $\sigma \supset A_{i}, P_{i}$ як неперервну множину проеціюючих променів $\{\mathrm{s}\}\left(\mathrm{s}_{\mathrm{i}} \supset A_{i} ; P_{i}\right)$, що відповідають миттєвим положенням точок $A$ і $p$. Для довільної точки $s(x, y, z) \in \sigma$, що знаходиться на промені $s_{i} \subset A_{i}, P_{i}$ в момент часу $t$ маємо такі відношення:

$$
\begin{gathered}
\frac{\Delta y-\left(v_{o} \cdot t+a \cdot t^{2} / 2\right)}{\Delta x+v_{o} \cdot t \cdot \cos \operatorname{arctg} k_{z}}=\frac{y-y_{01}}{x-x_{01}+v_{o} \cdot t \cdot \cos \operatorname{arctg} k_{z}} ; \\
\frac{\Delta z-v_{o} \cdot t \cdot \operatorname{sinarctgk}}{\Delta \mathrm{x}-\mathrm{v}_{\mathrm{o}} \cdot t \cdot \cos \operatorname{arctg}_{z}}=\frac{z-z_{02}}{z_{02}-x} ; \\
\left(\Delta x=\left|x_{02}-x_{01}\right|, \Delta y=\left|y_{02}-y_{01}\right|,=\left|z_{02}-z_{01}\right|\right) .
\end{gathered}
$$

Після підстановки значення

$$
t=\phi(x, z)=\frac{\Delta z\left(x_{02}-x\right)-\Delta x\left(z-z_{02}\right)}{v_{o}\left[\left(z-z_{02}\right) \cdot \cos \operatorname{arctg} k_{z}+\left(x_{02}-\sin \operatorname{arctg} k_{z}\right)\right]}
$$

3 (1) отримуємо рівняння

$$
\begin{gathered}
\Delta y-\left(v_{o} \phi(x, z)+\frac{a}{2}(x, z)^{2}\right)\left(x-x_{01}+v_{o} \phi(x, z) \cos \operatorname{arctg} k_{z}\right)- \\
-\left(\Delta x+v_{o} \cdot \phi(x, z) \cdot \cos \operatorname{arctg} k_{z}\right)\left(y-y_{01}\right)=0,
\end{gathered}
$$

що визначає певну поверхню. У цьому випадку це поверхня третього порядку.

Ілюстрацією грамографічного відображення є епюр (див. рис. 2). На епюрі подано первинні (на рухомій 
площині $\pi$ ) $f_{1}^{\prime}$ і вторинні (перепроеційовані з $\pi$ на нерухомі координатні площини $x y, x z, y z){ }^{1} f_{1}^{\prime},{ }^{2} f_{1}^{\prime},{ }^{3} f_{1}^{\prime}$ проекції прямолінійної траєкторії $f_{1}$ прообразу (точки) $A$ в $\gamma \gamma \gamma$ відображенні.

$A_{0}, P_{0}, \pi_{0}$ - початкові положення прообразу $A$, центра проеціювання $P$, площини проекцій $\pi . f_{2}-$ траєкторія руху $P, f_{3}$ - напрямний вектор руху площини $\pi$. Усі рухи рівномірні, швидкість всіх елементів проеціювання однакова, рух одночасний. Такий режим руху названо канонічним.

Окрім розв'язання прямої задачі кінематичного проеціювання, яка переважно полягає у побудові проекції траєкторії руху об'єкта проеціювання, цей різновид проеціювання надає і можливість розв'язку зворотної задачі, а саме за відомою проекцією траєкторії руху об'єкта пошук його координат. Зворотна (локаційна) задача кінематичного проекційного відображення, як зазначено вище, полягає у визначенні положення прообразу $A$ за його образом $A^{\prime}$, тобто

$$
F^{1}: A^{\prime} \subset \pi \rightarrow A \subset \Pi
$$

у довільний момент часу $t$ (рис. 3).

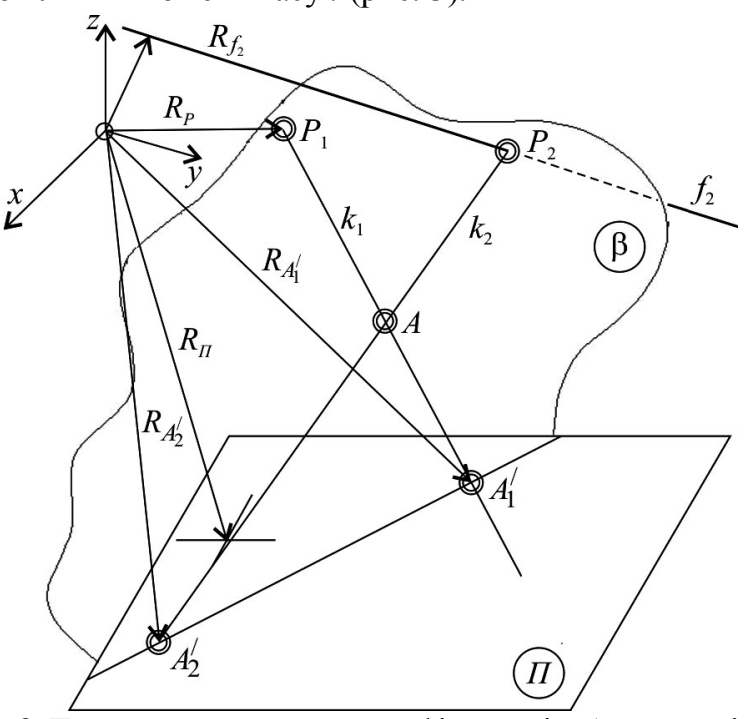

Рис. 3. Принципова схема грамографічного відображення рішення "оберненої задачі" на пошук об'єкта при кінематичному проеціюванні / Schematic diagram of the gramographic representation of the solution of the "inverse problem" for the search for an object in kinematic projection

Очевидно, що для ін'єктивності локації необхідно мати два компоненти $A_{1}^{\prime}, A_{2}^{\prime}$ образу $A^{\prime}$, отриманих проеціюванням прообразу $A$ із двох центрів $P_{1}, P_{2}$ (лінійні відображення) [1], або із двох конгруенцій (нелінійні відображення) [2]:

$$
F^{1}: A_{1}^{\prime}, A_{2}^{\prime} \frac{P_{i}, P_{2}}{(\ldots)} \rightarrow A ; F^{1}: A_{1}^{\prime}, A_{2}^{\prime} \frac{S_{1}^{2}\left(\phi_{1}, \phi_{1_{2}}\right), S_{2}^{2}\left(\phi_{2}, \phi_{2_{2}}\right)}{(\ldots)} \rightarrow A .
$$

Строго графічне (циркульне) розв'язання задачі можливе в однорідному просторі, тому що реалізується, в кінцевому підсумку, як перетин двох прямолінійних проеціюючих променів $s_{1}^{0}$ і $s_{2}^{0}\left(A=s_{1}^{0} \cap s_{2}^{0}\right)$ [2].

Прикладом виробничого використання кінематичного проеціювання може слугувати процес автоматизованого обробітку у відповідний спосіб облаштованих сільськогосподарських угідь. Його принципову схему відображено на рис. 4. До автоматизованого комплексу оброблення земельної ділянки тут входять оснащений приймальною антеною та системою дистанційного ке- рування виконавчий агрегат із функціональним навісним обладнанням для оброблення землі чи сільськогосподарських культур. Наприклад, трактор $з$ причіпним плугом, боронами чи косаркою, комбайн, моторизований обприскувач тощо. Переміщеннями моторизованого землеобробного механізму та його виконавчими агрегатами дистанційно керують із віддаленого пункту дистанційного керування, оснащеного комп'ютерною технікою із відповідним програмним забезпеченням, монітором для відстежування за переміщеннями землеобробної техніки та радіолокаційною станцією (РЛС) для прийняття та передачі радіосигналів відстежування та корегування роботами механізмів і агрегатів землеобробної техніки.

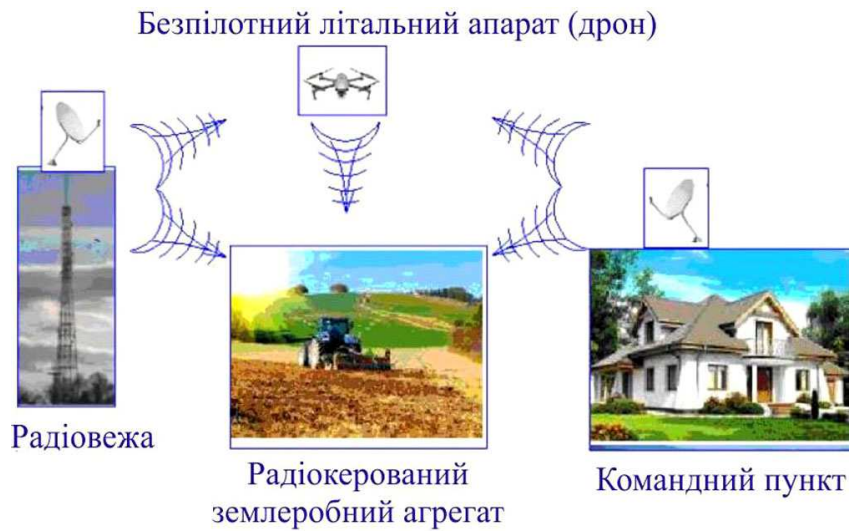

Рис. 4. Спеціалізований сільськогосподарський комплекс автоматизованого керування землеобробною технікою із використанням пульта керування / Specialized agricultural complex of automated control of tillage equipment with a remote control

Для усунення спотворення нерівностями земельної ділянки радіосигналів на ділянці додатково можуть облаштовувати допоміжну радіовежу із приймально-передавальною антеною. За відсутності радіовежі функції контролюючої приймально-передавальної ланки можуть бути покладеними на відповідно оснащений безпілотний літальний апарат (БПЛА). Літальний апарат, наприклад, дрон, літаючи чи "зависаючи" над оброблюваною ділянкою, сприйматиме керівні радіосигнали від пульта керування РЛС та надсилатиме на пульт керування інформативні сигнали про місце розташування землеобробної техніки.

Ця технологічна схема землеоброблення є прикладом можливості застосування принципів кінематичного проеціювання. Рухомий із певними швидкістю та прискоренням землеобробний агрегат тут є об'єктом проеціювання, що відстежує переміщення землеобробного агрегата, літальний БПЛА слугує у цьому випадку рухомим центром проеціювання. Екран комп'ютерного монітора на пульті управління тут відіграє роль "плаского носія інформації", тобто за термінологією нарисної геометрії "картинної площини проеціювання". Переважно тут на екрані висвітлюється траєкторія руху землеобробного агрегата та його можливі відхилення від неї. Ці відхилення піддаються негайному корегуванню. Ця система, за потреби, може відобразити в аксонометричному відтворенні також розташування та координати і землеобробного агрегата, і контролюючого БПЛА, тобто об'єкта й центра проеціювання. Однак переважно у цьому немає потреби, оскільки цілком достатньо зображення облаштованої на БПЛА чи радіовежі відеокамери. 
Отже, у цьому випадку, оперуючи складовими кінематичного проеціювання, тобто рухомим об'єктом проеціювання - землеобробним агрегатом, центром проеціювання - літальним БПЛА, а також "умовно рухомою із нульовою швидкістю" площиною проеціювання, можна забезпечити зведення до мінімуму можливих помилок людини-оператора. Адже в наявній технологічній схемі керівництво рухами та переміщеннями землеобробного агрегата здійснюється за зображеннями відеокамер у ручному режимі. I тут неминучий вплив так званого "людського чинника". Отже, застосування кінематичного проеціювання в технологічних схемах автоматизованого землеобробітку спроможне підвищити продуктивність та якість цього процесу завдяки усуненню можливих похибок операторів.

У цьому прикладі вдосконалення автоматизованого виробництва ми мали приклад вирішення так званої "прямої задачі" кінематичного проеціювання. Ця задача передбачає пошук i побудову на пласкому носії траєкторії (проекції) просторового переміщення об'єкта проеціювання, що рухається йз певними швидкостями. При цьому використовують дані про швидкість та траєкторію просторових переміщень одного центра проеціювання. У розглянутому прикладі у його ролі розглядали безпілотний літальний апарат (БПЛА).

Як приклад, одна із можливих у практичному застосуванні принципова схема розв'язання "оберненої" задачі кінематичного проеціювання полягає у їі використанні для визначення просторових координат невідомого безпілотного літального апарату за проекціями траєкторії його просторового переміщення. Суть проблеми полягає в тому, що через незначну масу цих розвідувальних апаратів (дронів) їх пошук у просторі як "матеріальної" точки або за шумовими ефектами ввімкненого двигуна вкрай ускладнений. Унаслідок цього спрямовані на ураження розвідувальних БПЛА засоби ППО, не володіючи точними координатами розташування ворожих розвідувальних БПЛА, малоефективні. Для цього необхідні точні координати розташування об'єкта в просторі. Саме це і спроможне забезпечити кінематичне проеціювання.

Із технічних засобів для виявлення просторових координат невідомого об'єкта, наприклад ворожого дрону-розвідника, тут використовують два оснащені радіопередавачами пошукові дрони № 1 та № 2. Цим пошуковим дронам у принциповій схемі відведено роль центрів проектування $P_{1}$ та $P_{2}$ (рис. 3). Зв'язок із пошуковими дронами здійснюється через оснащену відповідною комп'ютерною технікою із належним програмним забезпеченням наземною радіолокаційною станцією (РЛС).

Ця схема пошуку координат і траєкторій невідомих рухомих об'єктів є доволі універсальною і може застосовуватися як для їх пошуку в повітряному просторі, так і для визначення їх місця розташування на суші, на воді та у товщі води. Порівняно із наявними методами виявлення та знешкодження ворожих БПЛА-розвідників, які грунтуються на пошуку і виявленню цих літальних апаратів як "матеріального тіла певної маси", метод кінематичного проеціювання математично прораховує координати об'єкта як точки перетину проектуючих променів. А це і простіше, і точніше.

Переваги кінематичного проеціювання - спроможність визначення та відображення об'єкта на екрані комп'ютера не тільки у плоскому відображенні, а й із врахуванням його просторової координати по висоті, наприклад віддаленості від горизонту. Це дає змогу спостерігати за переміщеннями об'єкта не тільки у часовому інтервалі, а й у трикоординатному просторі.

Обговорення результатів дослідження. Результати дослідження дають змогу не тільки вдосконалити практику успішного застосування кінематичного проеціювання у сферах кінематографії $[6,7,12]$, архітектури і будівництва $[5,9,13]$ та геодезії $[1,2,3]$, а й відкривають перспективу успішного його використання і в інших галузях як національного господарства, так і у військовій сфері. Зокрема, воно має добрі перспективи використання у транспортних технологіях, землеобробітку та у землевпорядкуванні, включно із механізацією процесів висаджування саджанців дерев на великих за розмірами лісових ділянках.

Поряд 3 тим, на сучасному етапі становлення України як незалежної держави, що супроводжується активним залученням армії до провадження військових дій та операцій, особливої вагомості набуває і перспектива використання цієї дослідженої методології кінематичного проеціювання до визначення траєкторій та координат просторового розташування ворожої техніки на землі та воді, у повітрі та під водою. Однак на цьому етапі експериментальної перевірки теоретичних даних постає відчутна проблема наявності належного програмного комп'ютерного забезпечення. Хоча створення його не викликає жодних непоборних трудностей із теоретичної та практичної точок зору. Питання полягає, скоріш за все, в усвідомленні потреби у розвитку кінематичного проеціювання та наявності коштів на створення необхідного програмного продукту.

\section{Висновки / Conclusions}

Встановлено, що сучасний розвиток комп'ютерної техніки та її програмного забезпечення сприяє широкому практичному застосуванню кінематичного проеціювання. Це дає змогу відображати в проекційному зв'язку рухомі із взаємонезалежними швидкостями у просторі та часі класичні складові проеціювання, а саме його центр, об'єкт, проектувальний промінь та проекцію на "картинну площину".

Доведено, що розв'язання так званої "прямої задачі" кінематичного проеціювання передбачає можливість побудови на "картинній площині" проекцій траєкторії руху об'єкта проеціювання як у площинному, так і в аксонометричному відображеннях. Показано, що у практичному застосуванні це дає можливість задавання, відстежування та коригування траєкторій руху, наприклад, транспортних засобів, механізованих землеобробних засобів автоматизованих землеобробних комплексів тощо.

Досліджено, що розв'язання так званої "оберненої задачі" кінематичного проеціювання передбачає можливість пошуку координат руху та просторового місцерозташування об'єкта проеціювання за відомої траєктоpiï його руху. З'ясовано, що для цього використовують два рухомих незалежних центри проеціювання, перетин проектувальних променів яких відображає координати невідомого об'єкта, що підлягає ідентифікації. Встановлено, що застосування розв'язків "оберненої задачі" кінематичного проеціювання буде ефективним для пошуку в повітряному просторі літальних апаратів та нерозпізнаних об'єктів, а також для виявлення у товщі води 
рухомих плавучих засобів, зокрема: торпед, підводних човнів, підводних гідроциклів тощо.

\section{References}

1. Kalynovska, O. P., Hlohovskyi, V. V., \& Pulkevych, I. H. (1994) Neliniini operatory kinematychnykh proektsiinykh vidobrazhen. Pr. Lv. Mizh nar. nauk.-metod. konf. z heometrychnoho modeliuvannia, inzh. ta komp. hraf. Lviv, 36 p. [In Ukrainian].

2. Kalynovska, O. P., Hlohovskyi, V. V., \& Pulkevych, I. H. (1994). Lokatsiini zadachi kinematychnykh proektsiinykh vidobrazhen. Pr. Lv. Mizhnar. nauk.-metod. konf. $\mathrm{z}$ heometrychnoho modeliuvannia, inzh. ta komp. hraf. Lviv, 37 p. [In Ukrainian].

3. Kalynovskaia, O. P., Hlohovskyi, V. V., \& Pulkevych, Y. H. (1994). K probleme edynoi teoryy proektsyonnykh otobrazhenyi. Prykl. heom. y ynzh. hraf, 57, 45-50. [In Russian].

4. Kulmynskyi, O. K., \& Nykolaevskyi, H. K. (1971). Kynoaksonometryia kak metod obemno-hrafycheskoho modelyrovanyia. Prykl. heometryia y ynzh. hrafyka, 12, 136-138. [In Russian].

5. Kulmynskyiiu, O. K. (1967). Kynoperspektyva proektyruemoi avtomobylnoi dorohy. Candidate Dissertation for Technical Sciences. [In Russian].
6. Lykhachev, L. N. (1974). Ob odnom prymenenyy kynoperspektyvy. Sb. Heometrohrafyya. Ryha, 1. [In Russian].

7. Lykhachev, L. N. (1975). Kynoperspektyva. Moscow: "Vysshaia shkola", 248 p. [In Russian].

8. Lykhachov, L. N. (1955). Perspektyvno-priamouholnye sopriazhenye proektsyy. Nauchn.-tekhn.sb. Ryha, 19. [In Russian].

9. Mykhailenko, V. E., Obukhova, V. S., \& Podhornyi, A. L. (1972). Formoobrazovanye obolochek v arkhytekture. K., Budivelnyk. [In Russian].

10. Pulkevych, I. H. (1994). Liniini operatory kinematychnykh proektsiinykh vidobrazhen. Pr. Lviv. Mizh nar. nauk-metod. konf. z heometrychnoho7 modeliuvannia, inzh. ta komp. hraf. Lviv, 35 p. [In Ukrainian].

11. Pylypaka, S. F. (1991). Prymenenye metodov nachertatelnoi heometryy dlia nakhozhdenyia skorostei proyzvolnykh tochek tverdoho tela, sovershaiushcheho prostranstvennye dvyzhenyia. Prykl. heometryia y ynzh. hrafyka. K., 51, 62-64. [In Russian].

12. Rynyn, N. A. (1936). Kynoperspektyva. Moscow: Kynofotoyzdat. [In Russian].

13. Tkach, D. Y. (1968). Nekotorye voprosy kynoperspektyvy y postroenye arkhytekturnykh perspektyv. Yzd. vyssh. uch. zaved., ser. "Stoytelstvo y arkhytektura", No. 2, Novosybyrsk. [In Russian].

I. H. Svidrak, L. I. Shevchuk, O. I. Strogan, L. R. Strutynska, I. V. Strogan

Lviv Polytechnic National University, Lviv, Ukraine

\section{KINEMATIC PROJECTION AS A MEANS OF TECHNOLOGY CONTROL IN AUTOMATED TILLAGE COMPLEXES}

The method of application of kinematic projection for display of a trajectory of movement and search of coordinates of moving objects is described. In kinematic projection, all its key components, namely the object, the center of projection, the image plane and the projecting rays, are in continuous motion with certain speeds and accelerations. Kinematic projection deepens the field of practical application of descriptive geometry. This is confirmed by the example of practical application of kinematic projection presented in the article for improvement of remote control of tillage equipment in automated land treatment complexes. The main technical support for the practical application of kinematic projection is provided by stationary radio towers or unmanned aerial vehicles (BPLA), such as drones. They are equipped with video cameras and electromagnetic radiation devices. This equipment serves as a center of kinematic projection. The projecting rays generated by the projection center will be received by a stationary command post (center). It is equipped with a radar system (radar) and modern computer equipment with appropriate software. This equipment, in this case, performs the function of a "picture plane", that will reflect the trajectory of agricultural machinery. Actuators and controls of the movement of tillage equipment are equipped with receivers of control radio waves and means of automated control. The use of kinematic projection helps improve the quality of tillage. This is ensured by the fact that its use is carried out automatically and eliminates possible errors of operators. Kinematic projection can also be used in military affairs to detect enemy drones in the airspace. In this case, a kind of kinematic projection with its two centers of generation of projecting rays is used. This is an example of the solution of the so-called "inverse problem" of kinematic projection, which provides the ability to search for the coordinates of the motion of the projected object at a known trajectory of its motion. The main advantage of kinematic projection is the ability to identify and display an object on a computer screen not only in a flat view, but also taking into account its spatial coordinates.

Keywords: descriptive geometry; projection center; moving object; picture plane; tillage equipment; remote control; flying objects. 